RESEARCH ARTICLES

\title{
Modelling Social\&Communicative Skills in Children with Special Educational Needs
}

\section{Modelado de habilidades sociales y comunicativas en niños con necesidades educativas especiales}

\author{
Natalya Germanovna Sigal * \\ $\mathrm{PhD}$ in Pedagogy, Associate Professor, Department of Foreign Languages, \\ Institute of International Relations, Kazan Federal University \\ ORCID ID: 0000-0003-4602-035X
}

Irina Germanovna Kondrateva

$\mathrm{PhD}$ in Pedagogy, Associate Professor, Department of European Languages and Cultures, Institute of International Relations, Kazan Federal University

ORCID ID: 0000-0002-5829-8888

Received 09-08-20 Revised 10-10-20 Accepted 20-12-21 On line 03-01-21

* Correspondence

Email: sigaln@mail.ru

\section{Citation:}

Natalya Germanovna Sigal, Irina Germanovna Kondrateva. (2021) Modelling Social\&Communicative Skills in Children with Special Educational Needs. Propósitos y Representaciones, $\quad$ 9(SPE2), e1046. http://dx.doi.org/10.20511/pyr2021.v9nSPE2.1046 


\section{Summary}

The paper covers the issues of theoretical frameworks that are being developing around the process of modelling social communication skills in children with special educational needs during language learning process using interactive teaching techniques. This draws from a wide range of philosophical and psychological works on social and pedagogical rehabilitation of children with special educational needs as one of priority zones in the world policy and educational system aimed at growing attention to widespread acceptance of people with different needs in all spheres of society. Methodology used in the study is theoretical, empirical, methods of collecting data, description and dealing out the outcomes of the research. The study reflects empirical analysis based on observation, interviewing, testing and pedagogical experiment, which took place in the secondary school № 2 of the Republic of Tatarstan, Russia. Innovative ways of engaging social communication in teaching, learning and research led to designing a model for forming social communication skills in children with special educational needs via foreign language learning. The major findings of the research are the created model that makes possible to develop social and communicative skills; implementation of conditions of the development of these skills during pedagogical process; criteria of capacity for development of social and communicative skills of children with special educational needs.

Keywords: communication, social skills, foreign language, learning

\section{Resumen}

El artículo cubre las cuestiones de los marcos teóricos que se están desarrollando en torno al proceso de modelar las habilidades de comunicación social en niños con necesidades educativas especiales durante el proceso de aprendizaje de idiomas utilizando técnicas de enseñanza interactivas. Esto se basa en una amplia gama de trabajos filosóficos y psicológicos sobre la rehabilitación social y pedagógica de los niños con necesidades educativas especiales como una de las zonas prioritarias en la política mundial y el sistema educativo con el objetivo de prestar una mayor atención a la aceptación generalizada de personas con necesidades diferentes en todas las esferas de la educación. sociedad. La metodología utilizada en el estudio es teórica, empírica, métodos de recopilación de datos, descripción y tratamiento de los resultados de la investigación. El estudio refleja un análisis empírico basado en la observación, entrevistas, pruebas y experimento pedagógico, que tuvo lugar en la escuela secundaria № 2 de la República de Tartaristán, Rusia. Las formas innovadoras de involucrar la comunicación social en la enseñanza, el aprendizaje y la investigación llevaron al diseño de un modelo para formar habilidades de comunicación social en niños con necesidades educativas especiales a través del aprendizaje de lenguas extranjeras. Los principales hallazgos de la investigación son el modelo creado que posibilita el desarrollo de habilidades sociales y comunicativas; implementación de las condiciones del desarrollo de estas habilidades durante el proceso pedagógico; criterios de capacidad para el desarrollo de habilidades sociales y comunicativas de niños con necesidades educativas especiales.

Palabras clave: comunicación, habilidades sociales, lengua extranjera, aprendizaje.

\section{Introduction}

The search for effective approaches and technologies encouraging to the successful socialization of children with special educational needs as full members of society has been the focus of broad interdisciplinary scientific discussions around the world. Attention to the promotion of the idea in Russia is largely due to the adoption of the main international legal framework (the United Nations Convention on the Rights of the Child (1990), the Declaration of Human and Civil Rights and Freedoms (1991), the United Nations Convention on the Rights of Persons with Disabilities (2008)) and the development of a legislative framework for education and social guarantees for children with special educational needs: The Constitution of the Russian Federation (1993), the Law on Social Protection of Persons with Disabilities in the Russian Federation (1995), the Law on Education (1992), the Law on Ratification of the Convention on the Rights of Persons with 
Disabilities (2012) and the Law on Social Protection of Persons with Disabilities in the Russian Federation (2013).

At the same time, the system of inclusive education in Russia is at the initial stage of development, the typical characteristics of which are the passage of certain periods of turbulence, contradictions and barriers, largely due to the influence of stable stereotypes of differentiation of children by the presence or absence of any violation in their development and the need for them to receive education in two isolated systems: general and special education. There is a significant contradiction between the objective need to form social competences in children with special educational needs and the lack of a holistic scientific and theoretical study of this problem as a social and pedagogical phenomenon and the identification of successful practices of including these children in the system of various social interactions. This provision is contrary to the very idea of inclusion, whose humanistic potential is intended not only to eliminate the one-sided view of children with special educational needs, but also to become a leading mechanism for the creation of a tolerant society.

The problem of children with special educational needs acquiring a system of social competences that allow achieving maximum autonomy in society, acquiring the possibility of productive social interaction in various spheres of life, as well as acquiring the status of social sustainability in solving everyday tasks in various types of activities requires an urgent holistic scientific solution.

\section{Methodology}

The analysis of scientific literature on the topic made it possible to highpoint the issues connected with the concept of inclusive education (L. Cook, M. Friend, and others). The scientists H. M. Levin, A. Sander study the essence of inclusive education. M. Ainscow (2005), T. Booth, W. Stainback (1986) devoted the works to theoretical questions on the problem. Issues of practical realization of inclusive education are the interest of the scientists - M. Ainscow (2005), T. Booth (2011), T. Hellbrüge (1994), R.A. Villa (2008) and others.

Among Russian scientists studied the topic there are the works of S.B. Alekhina (2015), D.V.Zaitsev (2004), E.N. Kutepova (2015), N.N. Malofeev (1996), M. N. Nazarova (2012), A. A. Naumov (2011), N. Ya. Semago (2010) etc.

Theoretical basis of research is conceptual ideas of foreign and Russian scientists on the issues of Philosophy, History of Education, Pedagogy and Psychology: integrated teaching of children with special educational needs (A.G. Asmolov (1995), L.S. Vygotskiy (1983), E.L. Goncharova (2002); personal socialization (P. Burdie (2002), L. M. Shipitsyna (2010), N. D. Shmatko (1999), D. Zaitsev (2004), etc.); humanistic pedagogy (Sh.A. Amonoshvili (2001), R.A. Valeeva (1996), etc.).

The methods of studying scientific literature on the issue, analysis, systematization and generalization of the theoretical and empirical material, interviewing were used to define peculiarities, dynamics and contradictions in the development of inclusive education in Russia and abroad. Development and implementation of the model forming social skills of children with special educational needs was performed after theoretical and empirical analysis.

\section{Results}

Considering the model as a set of components that contribute to the production of the main sides, connections and functions of the subject matter of the study, we have developed a sociopedagogical model, which is a mutually agreed and interrelated unity of the following components and elements: target (purpose and objectives), methodological (principles and approaches); substantive (main areas of activity); procedural (pedagogical conditions, methods, forms, means); diagnostic (criteria and their indicators,). 
Considering that interactive techniques in teaching and learning languages can be one of the promising tools in the formation of social skills in children with special educational needs, this work should contribute to the implementation of an integrated approach in the triad of its components (communicative system-activity, personal-oriented and competent) based on taking into account the individual peculiarities of each child 's development, his/her capabilities and needs and be as focused as possible on restoring the balance between the physical and mental spheres of his/her development (Khuziakhmetov et al., 2018; Kondrat'eva \& Sigal, 2017; Plachova et al., 2019; Sabirova \& Khanipova, 2019).

\section{Description of the components of social and pedagogical model}

The target component is an important system element of the model, including the goal as an ideal result of the model functioning, the tasks as private (intermediate) goals involving certain actions to achieve intermediate results, as well as principles.

The leading goal of the model developed is the formation of social communicative skills in children with special educational needs. The objective is to: imitation;

- Development of motor skills, coordination of movements, strength, agility and complex communication;

Development of social interaction skills in the main spheres of activity and

- Increasing self-esteem, autonomy and discipline;

- Removal of emotional dewatering, aggression, fears.

The basis of the methodological component of the model developed is a set of the following principles:

The principle of humanization, which involves the implementation of a personal-oriented approach to the process of organizing psychological corrective work with children with special educational needs, within the framework of which a positive self-concept of each child is being developed;

- The principle of systemicity, which helps to build a holistic, regular and clear process, which ensures that children with special educational needs understand and the certainty of the scenario of interactions between all participants, reduces fear, anxiety and asocial behaviour;

- The principle of consistency, based on the step-by-step formation and development of the necessary social skills (interaction with surrounding objects and people, orientation in space, coordination of movements, communicative skills, etc.);

- The contextual principle, which implies the construction of the whole process of psychological correction work in the context of the formation of the necessary social skills in children with special educational needs, filling their activities with personal meaning, positive motivation towards the world around them and interaction with it;

- The problem principle, which ensures the updating of emotional-will, motivational, cognitive (memory, attention), social communicative-interactive (verbal and non-verbal) spheres of life of a child with special educational needs;

- The principle of dynamism, which consists in the progressive accumulation by children with special educational needs of personal experience of social interactions in the relationship and mental and emotional development;

- The principle of autonomy and activity, which ensures the purposeful and step-by-step formation and development of skills for performing motor actions in different situations of social interactions, which are the basis for the subsequent independent and active use of the acquired knowledge, soft skills in everyday life.

The implementation of these principles in the process of formation of social and communicative skills in children with special educational needs through foreign language learning is carried out within the framework of a set of the following approaches: communicative systemactivity, personality-oriented, competence-based. 
The fundamental basis of the substantive component of the model developed was the normative and legislative acts regulating pedagogical activities towards children with special educational needs in the Russian Federation:

Federal Law "Education in the Russian Federation";

Education Act of the Republic of Tatarstan; disabilities;

Federal State educational standard for primary general education for students with

Federal State Educational Standard for Primary General Education for Students with Autism Spectrum Disorders.

Also, the basis of the content component of the developed model was the course "Formation of social and communicative skills in the process of foreign language learning".

In the development of the procedural component, the system-forming vector was the design and development of a social and pedagogical environment that contributes to the successful socialization of the child with special educational need.

According to our deep conviction, based on the results of the theoretical study of the problem and personal experience carried out, the pedagogical conditions of implementation are as follows:

1) Increase of motivation based on development of individual route for psychological correction work by means of foreign language learning based on taking into account cultural development of each child, capabilities, detection of mechanisms of disorders (behavioral, emotional-will, motivational, cognitive, communicative). On the basis of the obtained data, an adapted training program is being developed;

2) Implementation of a comprehensive approach to the program of classes, in which the restoration of brain functions, is carried out through the performance of certain activities, ensuring harmonious and one-time development of mental and physical spheres in their interconnection with the implementation of social interaction (Goncharova \& Kukushkina, 2002). At the same time, the systemicity and step-by-step in the acquisition of skills by a child with special educational needs, as well as the absence of competition, time restrictions in the formation of social skills based on various interactions (Naumov, 2011), contribute to the consistent and gradual acquisition by the child of a system of skills for further broad socialization into society;

3) Strengthening of coordinated cooperation between teacher, psychologist, doctors and parents of children with special educational needs (Stainback et al., 1986). In this regard, ensuring team work between all participants of this process, carried out within the framework of a favourable and friendly environment, faith in the success of the child, professionalism of a teacher and various specialists, is intended to ensure the achievement of the goal and stability of the results obtained.

The stages of the process we model are as follows:

- Adaptive-diagnostic;

- Operational - active;

- Productive - reflexive.

A fundamental condition for the implementation of this model is the lack of time frame for the implementation of the program by children with special educational needs, due to the communication peculiarities of each child's development, their potential capabilities and needs. Therefore, it is impossible to objectively predict during what period the formation of a skill in each child will take place. Thus, for example, it is not uncommon for children with special educational needs with good intellectual abilities to have low motor activity (lack of coordination of 
movements, orientation in space, vestibular insufficiency, etc.), which creates great difficulties in acquiring social skills.

The methods used in the implementation of synthesis, individual talks, questionnaires), policy/non-policy direction of work (practical, verbal, visual, accession to the child's activities).

The forms of classes are exclusively group classes in inclusive groups that model the natural social environment.

In accordance with the wide range of autism manifestations and the characteristics of the individual needs of children with special educational needs, tutor (parents) are usually present in classes, providing children with the necessary assistance and support. Such organization of work allows not only to reduce in the child emotional-anxiety states, aggression, problems with communication, but also provides parents themselves with new and necessary tools in their interaction with the child, providing them with an opportunity to better understand their special world, opening up the potential about which they did not know. In this case, it is possible to talk not only about the educational, but also about the psychotherapeutic effect of this form of activity both for children with special educational needs and for their parents. In addition, the possibility of sharing experiences with other parents and providing mutual assistance and support is essential, which is generally intended to ensure the harmonization of the training program are: research methods (analysis of parent-child relations). Parents at home together with the child in the process of performing their homework practice the generated skill, performing the exercises studied in the lesson.

Means of implementation of the developed model are interactive techniques of learning such as "skill-based", "visual schedules", "structured teaching", "picture exchange communication system", "gentle teaching", based on combination of different developing exercises, operation with objects; accurate instructions of the teacher; lesson schedule.

The diagnostic component of the model includes the following: motivational; communicative and cognitive; technological.

The motivational criterion is the formation of a stable positive motivation to interact with the surrounding world and people in various communication situations. The indicators that reveal this criterion are: awareness of the personal significance, meaning and possibilities of social communication through verbal and non-verbal means; a sustained focus on adequate interaction.

Indicators of the communication and cognitive component are the following: ability to carry out cognitive activities through mental processes (perception, attention and memory) and performing logical operations; Ability to harmonize behavior (aggression, fear, moderation) and mental activity.

Among the technological criteria we consider the following indicators: ability to perform social functions independently in various types of activities; capacity for adequate and active social communications.

The effective component of the model developed is the formation in children with special educational needs a system of social competences or soft skills which ensure the possibility of independent performance of daily social and domestic functions, adequate and productive interaction with the surrounding world and people through verbal and non-verbal communication.

\section{Pedagogical experiment}

Experimental work to find out the effectiveness of the modeling social and communicative skills in children with special educational needs was carried out in the secondary school № 2 of the Republic of Tatarstan, Russia in 2018-2019. 
Based on the concept of the program of classes, according to which parents and children are full participants of trainings, 20 families participated in the experiment, of which 10 people are children with special educational needs, 10 people are their parents. The total number of people in each group was 20 (10 children and 10 from their parents). The total number of children of experimental group (EG) was 10.

In accordance with the leading goal of our study, we consider it appropriate to diagnose the formation of social competences in children with special educational needs in the context of the criteria of the diagnostic component of the pedagogical model developed: motivational, communicative-cognitive, competent.

Based on the understanding of the level as the degree of development of any quality, the following levels of development of the motivational component: zero, low, medium, high were established.

- Zero level - the child demonstrates lack of motivation to social interaction, closed, removed, aggression, fears are observed, does not allow to approach itself;

- Low level - there is little motivation for interaction;

- Medium level - shows interest in communication, does not express negative emotions when approaching it;

High level - motivation for social interactions is pronounced, demonstrates pleasure in communication and shows positive emotions.

Indicators of the level of development of the communication and cognitive component are as follows:

- Zero level - there is no desire to observe the behavior of other people, attention, unable to balance between mental and motor activity;

- Low level - partially demonstrates interest in cognitive activity, acts in the position of observer of behavior of other people, allows to approach to itself within a tightly established framework, there is moderation;

- Medium level - closely monitors others, there is coupled attention, memory is activated, attempts to harmonize motor and mental activity;

- High level - the desire for joint cognitive activity is clearly expressed, memory, attention are updated, logical operations are performed, mental and physical activity are harmonized.

Indicators of the level of development of the competency component are as follows:

- Zero level - unable to independently perform the necessary social and domestic actions (tightens the button, tie laces, etc.), social communication skills are absent;

- Low level - activity is carried out partially independently, social and household skills and social communication skills are fragmented;

Medium level - tries to perform tasks independently in various activities, to respond adequately to communication (verbal and non-verbal), but there are some difficulties;

- High level - is able to perform various social roles independently, with pleasure and full participation in social communication in different situations of communication.

Based on the concept of level-by-level development of mental entities proposed by L.S. Vygotskiy (Vygotskii, 1983), the set of levels of development of social competences in children with special educational needs can be represented by the following combinations:

- Zero level - variants of combinations, in which indicators of motivational, communicative-cognitive and competent components are at zero level;

- Low level - indicators of motivational and communicative-cognitive components are at low level, and competent at zero or low;

- Average level - indicators of motivational and communicative-cognitive components are at average or high level, and competent at average level;

- High level - variants of combinations, in which indicators of motivational and communicative-cognitive components are at high level, and indicators of competence on medium or high. 
Thus, indicators of levels of formation of social competences in children with special educational needs can be presented as follows:

- Zero level - the child demonstrates lack of motivation to social interaction, closed, removed, aggression, fears are observed, does not allow to approach itself; There is no desire to observe the behavior of other people, attention, unable to balance between mental and motor activity; is unable to perform the necessary social and domestic actions independently (tighten the button, tie laces, etc.), there are no social communication skills;

- Low level - partially demonstrates interest in cognitive activity, acts in the position of observer of behavior of other people, allows to approach to itself within a tightly established framework, there is moderation; activities are carried out partly independently, social and family skills and social communication skills are lacking/fragmented;

- Medium level - shows interest in communication, does not express negative emotions when approaching it/clearly expressed motivation to social interactions, shows pleasure in communication, shows positive emotions; closely watching others. There is coupled attention, memory is activated, attempts to harmonize motor and mental activity; Tries to carry out tasks independently in various activities, to respond adequately to communication (verbal and nonverbal), but there are some difficulties;

- High level - the motivation for social interactions is pronounced, demonstrates pleasure in communication, shows positive emotions, initiates communication; desire for joint cognitive activity, updated memory, attention, performs logical operations, mental and physical activity are harmonized; able to perform different social roles/functions independently, with pleasure and full participation in social communication in different situations of communication.

These criteria and indicators of the level of formation of social competences in children with special educational needs were used as the basis for the implementation of the pedagogical model developed at foreign language classes within the framework of the three main stages of experimental work.

At the first stage of our pilot work to determine the level of formation of the criteria for the level of formation of social skills in children with special educational needs, the following procedures were carried out:

1. Individual interviews with the child with special educational needs, his parents;

2. Monitoring the behavior and motivation of a child with special educational needs in the process of his inclusion in the system of exercises aimed at carrying out social interaction;

3. Analysis of the results of pedagogical tests to determine the level of development of general motor functionality, emotional-will sphere cognitive functions.

Individual discussions with children of this category were led in the form of the answer to a number of simple questions ("What is your name?", "How old are you?", "What favourite have you got?", "What you like to do most of all?", "With whom did you come? etc.), which made it possible to determine the need and ability of the child to communicate, the possibility of feedback.

In addition, an important point was the holding of individual interviews with the parents of children with special educational needs, which contribute to a deep and detailed understanding of the peculiarities of the development of the child, the history of the occurrence and manifestations of violations, as well as a personal attitude to the perception of the peculiarities of the development of their child, their alarming conditions, the level of their motivation for classes. It is the adequate perception by parents of the peculiarities of their child's development, the presence of maximum interest and readiness to participate in classes, the implementation of the necessary assistance and support to the child not only during trainings, but also in everyday life, trust in the teacher, faith in success contribute to the creation of a positive social and pedagogical environment and building of productive work.

The criteria and indicators of the tests performed are as follows:

0 points - the child does not show interest in performing exercises, cannot perform the exercise on his own; 
1 point - there is a small motivation to perform the exercise, but on its own can perform no more than $10 \%$ of the total volume of the test;

2 points - shows sufficient level of motivation, exercises are performed with the help of a tutor (parent) with verbal/non-verbal support of the teacher (from $10 \%$ to $90 \%$ of the total volume of the test);

3 points - motivation is pronounced, exercise is performed independently from the beginning to the end according to verbal/non-verbal signal of the teacher $(100 \%$ of the test volume).

Diagnostic results are interpreted on a 60-point scale, according to which:

- Low level of general communication functionality - from 0 to 20 points;

- Average level of general communication functionality - from 21 to 40 points;

- High level of general communication functionality - from 41 to 60 points inclusive.

On the basis of the obtained data the teacher develops an individual program of communication correction for each child, implementation of which is carried out within the framework of systematic group classes and in the mode of individual training of a skill with a tutor (parent) at home as a homework.

So, the essential condition for the realization of communication correction work on formation of social skills in children with special educational needs on the basis of foreign language classes is maximum consideration of individual peculiarities of development of each child, therefore the duration of trainings necessary for passing the final examination for transition from one level to another, can vary (increase or decrease) and has no strict time restrictions. It typically takes a period of one to two years.

\section{Analysis of the results of the pilot work on testing the effectiveness of social skills development in children with special educational needs using foreign language learning}

It was noted that the results of diagnostics are an indicative platform for assessing the initial level of formation of social skills in children with special educational needs and developing an individual route of communication correction work during foreign language classes.

As a result of the input diagnosis, the following results were obtained as shown in Table 1.

Table 1. Diagnostics of initial level of social skills formationin children with special educational needs

\begin{tabular}{|c|c|c|c|c|}
\hline Criterion & Zero & Low & Medium & High \\
\hline Motivational & $40 \%$ & $50 \%$ & $10 \%$ & - \\
\hline Communicative-cognitive & $30 \%$ & $60 \%$ & $10 \%$ & - \\
\hline Process & $70 \%$ & $20 \%$ & $10 \%$ & - \\
\hline
\end{tabular}

As can be seen from the table, the level of formation of social skills in most children is zero or low for all three criteria, only $10 \%$ of respondents have an average level, while no child has a high level. According to the variants of combinations of interpretation and systematization of the obtained diagnostic results, zero level of formation of social skills was revealed from the total number of diagnosed (20 people) was revealed in $40 \%$ of respondents, low level in $50 \%$ of respondents and $10 \%$ average level in $10 \%$ of respondents. The systematized results for each group prior to the start of the experiment are shown in Table 2.

Table 2. Data on the formation of social skills in children with special educational needs prior to the experiment

\begin{tabular}{|c|c|c|c|c|}
\hline Group & \multicolumn{4}{|c|}{ Level of social skills formation } \\
\hline & Zero & Low & Medium & High \\
\hline G 1 & $50 \%$ & $50 \%$ & - & - \\
\hline
\end{tabular}




\begin{tabular}{|l|l|l|l|l|}
\hline G 2 & $30 \%$ & $60 \%$ & $10 \%$ & - \\
\hline
\end{tabular}

A survey of parents was also conducted to determine their motivation to participate in classes, as well as to identify leading motives for including their children in foreign language class. This diagnosis is an important factor contributing to the efficiency of the whole process of communication correction work, according to the main idea underlying the model developed. The results of the questionnaire revealed the following dominant motives for choosing the program of foreign language classes: public opinion (30\% of respondents), other programs did not lead to the expected result ( $20 \%$ of respondents), desire to help socialize the child ( $40 \%$ of respondents), increase their self-esteem (10\% of respondents).Thus, it was possible to make that despite the difference of motives, the dominant motive can be considered the desire to help the child successfully socialize in the future, to remove from it a stamp of some inferiority and marginalization.

At the final stage the following results were obtained: jut of the total number of respondents $25 \%$ have a low level, $60 \%$ - a medium level, $15 \%$ showed a high level. The diagnostic results for each group are shown in Table 3.

Table 3. Data on the formation of social skills in children with special educational needs at the final stage of the experiment

\begin{tabular}{|c|c|c|c|c|}
\hline Group & \multicolumn{4}{|c|}{ Level of social skills formation } \\
\hline & Zero & Low & Medium & High \\
\hline G 1 & - & $30 \%$ & $60 \%$ & $10 \%$ \\
\hline G 2 & - & $20 \%$ & $60 \%$ & $20 \%$ \\
\hline
\end{tabular}

Summary data on the evolution of the level of formation of social competences within the three phases of experimental work are given in Table 4.

Table 4. Dynamics of the level of formation of social competences in children with RAS at three stages of the experiment

\begin{tabular}{|c|c|c|c|c|}
\hline Stages & \multicolumn{3}{|c|}{ Level of social skills formation } \\
\hline I & $40 \%$ & $50 \%$ & $10 \%$ & - \\
\hline II & $10 \%$ & $45 \%$ & $45 \%$ & - \\
\hline III & - & $25 \%$ & $60 \%$ & $15 \%$ \\
\hline
\end{tabular}

\section{Conclusions}

The effective component of the model developed is the formation in children with special educational needs of a system of social competences, which ensure the possibility of independent performance of daily social and domestic functions, adequate and productive interaction with the surrounding world and people through verbal and non-verbal communication.

As part of the implementation of this model, the increase in the level of formation of social competences in children with special educational needs based on the foreign language learning took place systematically, consistently and gradually, which eventually resulted in the absence of zero respondents, a decrease in the number of low-level respondents and an increase in the number of middle-level and high-level respondents. 


\section{Acknowledgements}

The work is performed according to the Russian Government Program of Competitive Growth of Kazan Federal University.

\section{REFERENCES}

Ainscow, M. (2005). From Special Education to Effective Schools for All. Keynote presentation at the Inclusive and Supportive Education Congress, University of Strathclyde, Glasgow.

Alekhina, S. V. (2015). Zolotoe sechenie: psikhologicheskaya kanva inklyuzii", Inklyuzivnoeobrazovanie, Moscow: Klassnoe rukovodstvo i vospitanie shkol'nikov, 224p.

Amonashvili, Sh.A. (2001). Razmyshleniya o gumannoi pedagogike. M.: Izdatel'skii dom Shalvy Amonashvili, 464p.

Asmolov, A.G. (1995). Strategiya razvitiya variativnogo obrazovaniya: mify i real'nost. Magistr, 1 , 23-27.

Booth, T., Ainscow, M., \& Kingstone, D. (2011). Index for inclusion developing play, learning and participation in yearly years and childcare. Bristol, UK: Centre for Studies on Inclusive Education: CSIE, May.

Burd'e, P. (2002). Opyt refleksinoi sotsiologii. Teoreticheskaya sotsiologiya: Antologiya: v 2 ch. per. s angl., fr., nem., it. / Sost i obshch. red. S.P. Ban'kovovskoi, Moscow: Knizhnyi dom «Universitet», , 424p.

Goncharova, E.L., \& Kukushkina, O. L. (2002). Rebenok s osobymi obrazovatel'nymi potrebnostyami. Al'manakh instituta korrektsionnoi pedagogiki RAO, 5, 35-45.

Hellbrüge, T., Fritz, L., Menara, D., Schamberger, R., \& Rautenstrauch, T. (1994). Monachijska Funkcjonalna Diagnostyka Rozwojowa. Kraków: Antykwa, 80-130.

Khuziakhmetov, A. N., Valeev, A. A., \& Kralova, Z. (2018). The most important aspects of early foreign-language education in primary schools. XLinguae, 11(2), 370-382.

Kondrat'eva, I. G., \& Sigal, N.G. (2017). Obuchenie inostrannomu yazyku v inklyuzivnoi obrazovatel'noi srede vuza", Materialy mezhd. nauch.-prakt. konf. "Yazyk i kul'tura nauchnogo $\mathrm{v}$ epokhu integratsii nauchnogo znaniya i professionalizatsii obrazovaniya", 16-17 marta, FGBOU VO "PGU", Pyatigorsk, 40-45.

Kutepova, E. N. (2015). Usloviya polucheniya obrazovaniya rebenkom s OVZ, Inklyuzivnoe obrazovanie, Moscow: Klassnoe rukovodstvo i vospitanie shkol'nikov, 21-33.

Malofeev, N. N. (1996). Spetsial'noe obrazovanie v Rossii i za rubezhom: V 2-kh chastyakh. Chast' 1 Zapadnaya Evropa / N.N.Malofeev - Moscow: «Pechatnyi dvor», 182p.

Naumov, A. A. (2011). Tekhnologicheskaya model' realizatsii inklyuzivnogo obrazovaniya v usloviyakh obshcheobrazovatel'noi shkoly", Inklyuzivnoe obrazovanie: metodologiya, praktika, tekhnologiya: materialy mezhdunarodnoi nauchno-prakticheskoi konferentsii (20-22 iyunya 2011, Moskva). - Moscow: MGPU, 142-144.

Nazarova, N. M. (2012). Sistemnye riski razvitiya inklyuzivnogo i spetsial'nogo obrazovaniya v sovremennykh usloviyakh. Spetsial'noe obrazovanie, 3(27), 6-12.

Plachova, E. A., Kharapudko, E. N., \& Nurmieva, R. R. (2019). Game techniques as a method of the educational process intensification in the teaching a foreign language. Humanities and Social Sciences Reviews, 6, 38-44.

Sabirova, D. R., \& Khanipova, R. R. (2019). Innovative approaches to teaching and learning english as second and english as foreign language in multilingual education. Humanities \& Social Sciences Reviews, 7(6), 45-48.

Semago, N. Ya. (2010). Opyt sistemnogo razvitiya inklyuzivnogo obrazovaniya v Tsentral'nom okruge. Inklyuzivnoe obrazovanie. Vypusk 1, Moscow: Tsentr «Shkol'naya kniga», 1825.

Shipitsina, L. M. (2010). Integratsiya i inklyuziya: problemy i perspektivy (materialy rossiiskogo foruma «Pediatriya Sankt-Peterburga: opyt, innovatsii, dostizheniya» (20-21 sentyabrya 2010g.), Saint Petersburg, - 200p.

Shmatko, N. D. (1999). Dlya kogo mozhet byt' effektivnym integrirovannoe obuchenie?, 1, 41-45. 
Stainback, W., Stainback, S., \& Bunch, G. (1986). Introduction and historical background. In S. Stainback, W. Stainback, \& Forest, M. (Eds.), Educating all students in the mainstream of regular education, Baltimore: Paul H. Brookes,.

Valeeva, R. A. (1996). Gumanisticheskoe vospitanie: Opyt reformatorskikh shkol Evropy pervoi poloviny XX veka. Kazan: Kaz. ped. un-t, 173p.

Villa, R. A., \& Thousand, J. S., \& Nevin, A. L. (2008). A guide to co-teaching: Practical tips for facilitating student learning (2nd ed.)", Thousand Oaks, CA: Corwin Press.

Vygotskii, L. S. (1983). Sobranie sochinenii: v 6 t. T.5. / pod red. T.A.Vlasovoi, Osnovy defektologii, Moscow: Pedagogika, 369p.

Zaitsev, D. V. (2004). Sotsial'naya integratsiya detei s ogranichennymi vozmozhnostyami: dis. ... doktora. sots. nauk: 22.00.04 / Zaitsev Dmitrii Viktorovich. - Saratov, -360p. 